обстоятельств, способных повлечь за собой те или иные ограничения прав и свобод.

Законодательная регламентация условий и порядка применения физической силы, специальных средств и оружия сотрудниками правоохранительных структур явно доминирует над общими условиями, вытекающими из принадлежащего каждому субъективного права необходимой обороны. Упоминание же о нем в соответствующих законодательных актах чаще всего относится лишь к ситуациям использования сотрудниками подручных средств. Таким образом, исходный приоритет права необходимой обороны и других обстоятельств, исключающих преступность деяния, в отношении пусть и установленных законом регламентов явно нарушается. Таким образом затушевывание на практике существа трансформации исходных субъективных прав в полномочия органов и сотрудников правоохраны приводит к подмене первых вторыми. И поскольку объективация субъективных прав носит регламентарный характер, то она неизбежно приводит к ограничению права необходимой обороны в отношении сотрудников правоохранительных органов. [5]

Такая ситуация должна расцениваться как противоречащая закону и ущемляющая субъективные права граждан-сотрудников правоохранительных структур, что в силу конституционных положений недопустимо

Очевидно, эффективность реализации института необходимой обороны во многом может быть повышена за счет четкой законодательной регламентации условий правомерности защитных действий, предпринимаемых в целях пресечения общественно опасных посягательств.

Защита путем акта необходимой обороны будет лишь тогда правомерной и исключающей преступность деяния, если она отвечает ряду определенных условий, которые в своей совокупности свидетельствуют о правомерности необходимой обороны.

\section{Список использованных источников}

Косарев А. В. Актуальные проблемы института необходимой обороны. //Автореферат диссертации на соискание ученой степени кандидата юридических наук. Ростов-на-Дону, 2001. - 254 c.

Ткаченко В.И. Необходимая оборона по уголовному праву// М., МГУ, 2000г. - 476 с.

Якубович М.И. Вопросы теории и практики необходимой обороны, М., 2003, С.105-106.; Козак В.Н. Указ.соч., С.81.; Баулин Ю.В. Указ.соч., С.247.

Кондрашова Т.В. Проблемы уголовной ответственности за преступления против жизни, здоровья, половой свободы и половой неприкосновенности. //Екатеринбург, 2000. С. 170.

Кожабаев Ж.О. «Преступное нападение как основание применения необходимой обороны»//Вестник КазНУхабаршы, серия юридическая, №4(52), 2009 - 135-138 с.

\title{
ENVIRONMENTAL LAW REFORM: HISTORY AND PROSPECTS
}

DOI: $10.31618 /$ ESU.2413-9335.2019.6.69.505

Кыдыров Женис Серикбаевич

Магистрант кафедры международного права юридического факультета Евразийского Национального университета имени Л.Н.Гумилева

\section{АННОТАЦИЯ}

В статье проанализированы понятия «законодательство», его содержание применительно экологической отрасли, субъективные и объективные факторы, способствовавшие становлению экологического законодательства как самостоятельной отрасли в Казахстане. Обобщены наиболее сущностные характеристики экологического законодательства.

\section{ABSTRACT}

The article analyzes the concept of «legislation», its content in relation to the environmental industry, subjective and objective factors that contributed to the formation of environmental legislation as an independent industry in Kazakhstan. The most essential characteristics of environmental legislation are summarized.

Ключевые слова: экологическое право, окружающая природная среда, экологическая безопасность, экологический мониторинг.

Key words: environmental law, environment, environmental safety, environmental monitoring.

Human and civil rights are divided into several groups: personal or civil, economic, political, social, environmental, cultural and information. A special place among these rights is occupied by environmental human rights [1].

Environmental human rights derive from the basic constitutional law of each person, which is enshrined in part 1 of Article 15 of the Constitution of the Republic of Kazakhstan - the right to life.

Article 31 of the Constitution of the Republic of Kazakhstan determines that the state sets the goal of protecting the environment favorable to human life and health [2]. This means that the state guarantees a person living in normal conditions that meet the requirements of standards and requires that everyone comply with the requirements for environmental protection and protection.

The environmental rights of citizens are enshrined in article 13 of the Environmental Code of the Republic of Kazakhstan. So, the basic environmental rights are: the right to an environment favorable to their life and health; the right to establish public associations and 
environmental funds; the right to participate in the decision-making process by state bodies on issues related to the environment; the right to participate in meetings, rallies, pickets, marches and demonstrations, referenda in the field of environmental protection; the right to appeal to state bodies with letters, complaints, statements and proposals on environmental issues and to require their consideration; the right to receive timely, complete and reliable environmental information from government bodies and organizations; the right to sue for damages caused to their health and property as a result of violation of environmental legislation [3].

The right to a favorable environment is one of the main environmental human rights. The legislative definition of a favorable environment in the Republic of Kazakhstan was given in the "Environmental Code of the Republic of Kazakhstan" dated January 9, 2007, in which "the environment, the state of which ensures environmental safety and protecting public health, preserving biodiversity, preventing pollution, and sustainable functioning, is recognized as a favorable environment" ecological systems, reproduction and rational use of natural resources "[3].

The natural environment consists of the concepts of nature and the human environment and serves as a condition and means of human life, the territory in which he lives, as well as a place for the placement of production facilities that provide his own useful activities. Thus, the natural environment forms a complex concept, within the framework of which two main forms of interaction between society and nature have historically been developed.

The first is the use of nature to satisfy a person's material and spiritual needs. The second is environmental protection in order to preserve man himself and other natural resources (objects), again in the interest of man.

The consumption and irretrievable withdrawal of renewable natural resources in some respects already exceeds the ability of natural systems to self-reproduce. This is one of the main problems in the field of environmental protection [4].

Therefore, everyone should be aware of the value of the natural environment and thereby not harming the natural environment, create favorable living conditions for themselves and be able to protect their violated environmental rights.Environmental law is a set of legal norms designed to regulate people's behavior in relation to the environment. Our position is that environmental law and land, water, forest, mountain, faunistic, atmospheric law are independent branches of law and are part of a comprehensive, integrated branch of law - environmental law. Relations on the use of natural resources will be regulated within a separate industry - land, water, etc. - but from the perspective of the general objectives of environmental law.

Thus, on the basis of the foregoing, the following definition of environmental law can be given - this is an integrated, comprehensive branch of modern law that includes a set of legal norms regulating environmental relations that arise between the state and its subjects regarding interaction with natural and individual natural resources [5].

The development of environmental legislation is an important part of legal reform in the Republic of Kazakhstan.

The first stage of transformation of environmental legislation, which ended in the summer of 1997 with the adoption of a new law "On Environmental Protection", is an important step towards improving the environmental situation and the transition of the Republic of Kazakhstan to sustainable development. The development of the system of environmental legislation in the republic is determined by the need for a transition from a narrow consumer natural resource to universal legal regulation of all aspects of the interaction between society and nature.

The development of the environmental legislation system of independent Kazakhstan is closely connected with the processes of political and socio-economic modernization taking place in Kazakhstani society. With the collapse of the USSR and the formation of a new sovereign state in 1991, in our opinion, a new stage in the development of the environmental legislation of Kazakhstan has begun [6].

The first stage of development of the environmental legislation of independent Kazakhstan, began in 1991 and ended in 1995 with the adoption of the Constitution, which also corresponds to the staged political and socio-economic development of Kazakhstan society, highlighted by the President of the Republic of Kazakhstan N. Nazarbayev [7].

In the context of basic legislation, the 1993 Law on Environmental Protection should be mentioned. Along with these laws, at the first stage from 1991 to 1995 a number of codified legislative acts were adopted that regulate the use and protection of certain types of natural resources. In particular, in 1992, the Code "On Subsoil and Processing of Mineral Raw Materials", the Laws "On the Social Protection of Citizens Affected by Nuclear Tests at the Semipalatinsk Test Site", and "On the Social Protection of Citizens Affected by the Ecological Disaster in the Aral Sea"; in 1993 - the Forest Code, the Water Code, the Law of the Republic of Kazakhstan "On the Protection, Reproduction and Use of the Animal World"; in 1994 - the Law of the Republic of Kazakhstan "On the sanitary and epidemiological welfare of the population". On June 28, 1995, a Decree was signed with the force of the Law on Oil.

The first stage of development of the environmental legislation of Kazakhstan is characterized by updating the main most important acts, for example, legislation on mineral resources, water and forest resources; adoption of laws on social protection of citizens affected by the activities of the Semipalatinsk nuclear test site and the Aral disaster. The environmental legislation of this period has the following features.

Firstly, the environmental legislation of the republic in terms of content and form corresponded to the environmental legislation of the USSR. Legislative acts were developed in the image and likeness of similar laws in force in Soviet times. This similarity 
was observed not only in the development of environmental legislation, but also in all branches of the legislation of the CIS countries, which was due to the fact that the states that make up the community previously represented one country with a clearly centralized planned economic system and uniform legislation. In addition, legislative practice was established in the former USSR, in which republican legislation actually reproduced union legislation [8].

Secondly, environmental legislation during this period was aimed primarily at regulating relations in the use and protection of certain natural resources. Based on a comparative analysis of the environmental legislation of the CIS countries, earlier in our work we noted that environmental legislation in all post-Soviet republics developed in approximately the same directions, and industry-specific natural resource legislation codified in resource codes prevailed in its structure [8].

Thirdly, environmental laws contained only general principles, poorly reflected measures to prevent environmental pollution. The environmental legislation of the first stage has lost its ability to ensure environmental well-being very quickly. As noted, this phase lasted only 5 years. The reason for this was Kazakhstan's entry into the global market economy, the need to develop production of both the public and commercial sectors, which requires the use of natural resources, the sale of natural resources for export and their import, which also caused the transition of legislation to a new plane, since the legislation of the first stage did not could regulate market relations.

The second stage of development of environmental legislation, covering the years 19962000 , led to the replenishment of the environmental legislation of the republic mainly with such environmental legislative acts as: "On Subsoil and Subsoil Use” of January 27, 1996, "On Environmental Protection”, of July 15 1997, “On Specially Protected Natural Territories" dated July 15, 1997, “On Environmental Expertise" dated March 18, 1997. The second stage of development of the environmental legislation of the republic is characterized by the intensive development of the environmental protection subsystem of ecological nical legislation, aiming at the highest possible capacity gaps, creating a balanced system of legal acts.

The main directions of development of environmental legislation were determined by the Concept of legal policy of the Republic of Kazakhstan, approved by the Decree of the President of the Republic of Kazakhstan dated September 20, 2002. The implementation of the provisions of the Concept of Legal Policy, as well as the development of market relations and the formation of their organizational and economic structures, profound transformations in the social sphere, improvement of public administration by delimiting powers between levels of government, as well as the development of environmental management in the new conditions necessitated the improvement of water, land, forest legislation and, on its basis, adaptation of water, land and forest management systems resources to the requirements of the time.
So, during this period the following most important legislative acts were adopted: the Law of the Republic of Kazakhstan "On Air Protection" of March 11, 2002, the Land Code of June 20, 2003, the Forest Code of July 8, 2003, and Water of July 9 2003, Laws "On the Protection, Reproduction and Use of the Wildlife of July 9, 2004,“ On Compulsory Environmental Insurance "of December 13, 2005, and“ On Specially Protected Natural Territories "of July 7, 2006.

The next stage in the formation of Kazakhstani environmental legislation was the adoption in 2007 of the Environmental Code of the Republic of Kazakhstan. The Environmental Code was developed in order to implement the tasks identified by the Head of State N.A. Nazarbayev in his Message to the people of Kazakhstan dated March 1, 2006, "Kazakhstan is on the threshold of a new market ahead of its development". This strategic document set the task of reforming environmental legislation aimed at ensuring environmental safety in accordance with international standards, with the aim of assisting our country to become one of the 50 most competitive countries in the world [9].

In this Code, the level of environmental safety is brought in accordance with international standards, which is oriented towards advanced technologies.

In connection with the adoption of this Code, laws such as "On Environmental Protection", "On Air Protection", "On Environmental Expertise" and a number of by-laws have become invalid. The Environmental Code consists of the General Part and the Special Part.

The special part consists of two sections: environmental requirements in carrying out business and other activities and responsibility for environmental violations and the resolution of environmental disputes.As can be seen from the contents of the Environmental Code contains all aspects of environmental protection. The Code also enshrines the list of nature objects subject to legal protection, indicates the main environmental requirements for economic and other activities. It should be especially noted that the Code includes aspects of environmental education and training, provisions fixing the system of bodies of state power and management in the field of environmental protection, etc., in particular, Chapter 25 of the Code.

The implementation of environmental policies in the field of international cooperation is carried out in the form of accession to previously adopted international conventions and agreements, the conclusion of new international treaties at the regional or bilateral levels, followed by legislative measures at the national level. Kazakhstan's participation in international environmental conventions contributes to the country's inclusion in the global environmental process. Kazakhstan acceded to the most important international conventions on climate change, combating desertification and biodiversity conservation, ratified the Aarhus and transboundary Conventions of the European Economic Commission (ECE), UN, Kyoto Protocol, became a member of the 
UN Sustainable Development Commission. Currently, the Republic of Kazakhstan has 22 ratified environmental international conventions, about 10 codes and 18 laws, as well as more than 300 special bylaws that directly or indirectly regulate certain areas of interaction between society and nature and, characterizing the current legislation in the field of environmental protection.

And also, the following legislative acts were adopted, due to the need to tighten environmental requirements, involve renewable energy sources in the economy, determine and clarify the competence of environmental state authorities in connection with ongoing changes in the economic sphere:

- The Law of the Republic of Kazakhstan "On Amendments and Additions to the Water Code of the Republic of Kazakhstan” dated February 12, 2009, aimed at determining legal relations in the field of water supply and sanitation;

- The Law of the Republic of Kazakhstan "On Amendments and Additions to the Environmental Code of the Republic of Kazakhstan on the Regulation of the Importation of Environmentally Hazardous Technologies, Machinery and Equipment" dated June 23, 2009, developed for implementation. Messages from the Head of State to the people of Kazakhstan "New Kazakhstan in a New World" dated February 28, 2007 on toughening environmental requirements in the field of the use of hazardous technologies and equipment;

- Laws of the Republic of Kazakhstan "On Supporting the Use of Renewable Energy Sources" and "On Amending and Adding to Some Legislative Acts of the Republic of Kazakhstan on Supporting the Use of Renewable Energy Sources" dated July 4, 2009, aimed at creating a legal framework for the use and development of renewable sources energy in the republic;

- The Law of the Republic of Kazakhstan "On Amendments and Additions to Certain Legislative Acts of the Republic of Kazakhstan on the Issues of Compliance with Water Conservation and Environmental Protection Discipline in Urban Planning, Land Allocation, Design and Construction" dated July 10, 2009, aimed at filling the gaps in the existing legislative acts in parts of compliance with water protection and environmental standards in urban planning of territories and allocation of land for development;

- The Law of the Republic of Kazakhstan "On Subsoil and Subsoil Use" of June 24, 2010, aimed at the rational and comprehensive study and use of subsoil. Ratification by Kazakhstan in 2009 of the Kyoto Protocol to the UN Convention on Climate Change and the need to fulfill international obligations under it identified further trends in the development of Kazakhstani environmental legislation.

So, in recent years, Kazakhstan has been undergoing an active process of revising important legislative acts, numerous changes and additions are being made to existing laws. Meanwhile, the frequent change and addition of laws and other normative legal acts emasculates their original essence, the philosophy that lay at the basis of their development. Here is a good example: over the past few years, various changes and additions have been made to the Environmental Code of the Republic of Kazakhstan ten times, of which, only in 2016 - six times. The Law of the Republic of Kazakhstan "On Subsoil and Subsoil Use" has also been amended a lot. All these legislative novelties inherently did not carry any serious legal novelty, they were aimed at solving various economic and social problems, as well as at solving minor administrative issues. At the same time, these tasks and issues were and must be resolved by applying economic, market mechanisms, by improving contractual practices, and not by making changes and additions to laws [10].

Despite all the progressive ideas of the existing environmental legislation, practice has revealed certain gaps and contradictions. The existing system of regulation of environmental issues is justly criticized by experts and foreign observers who note that Kazakhstani law and practice of its application are intended to punish the nature user, but not to restore and preserve the environment.

In 2007, the Environmental Code was adopted, which aims to systematize the entire regulatory framework, improve the system of regulation, state control and other institutions, as well as introduce advanced international standards in the practice of nature management and environmental protection. At the same time, certain regulations of the current legislation do not fulfill a socially useful goal, create unjustifiably high administrative barriers to entrepreneurship and have a high corruption potential. The existing legal regulation on environmental damage compensation is not primarily aimed at restoring the state of natural objects, but is used as a tool to replenish the state budget with funds that are not used to solve environmental problems.

According to experts, the lack of an effective state system for monitoring the pollution of environmental components is also a big problem. The reduction in the number of gauging stations and posts for monitoring atmospheric air has led to the fact that at present many regions of Kazakhstan do not even have background indicators of pollutants in the air and in water sources. Therefore, when calculating the standards, specialists have to use the reference data of the Soviet period. For soils, most small rivers, groundwaters, and atmospheric air in vast territories of the Republic of Kazakhstan, there are practically no objective data that could be used in environmental activities.

Since 2013, numerous meetings have been held with environmental associations, which discussed the provisions of the Environmental Code, as well as bylaws regarding the regulation of greenhouse gas emissions. Based on the results of the meetings and legal monitoring, it was established that there are gaps in the provisions and norms of the Environmental Code and approaches have been identified to address them.

The draft Code proposes:

1) provide for the mandatory development of a national strategic program for low-carbon development, including 16 regions and cities with a 
population of more than one million inhabitants (Astana, Almaty and Shymkent);

2) consider improving the mechanism for issuing quotas for greenhouse gas emissions in order to stimulate low-carbon production;

3) provide compensation mechanisms with the indirect participation of plant operators in decarbonization. For example, compensation for the costs incurred in paying for the "green" tariff by converting the acquired volume of green electricity into a quota;

4) take into account the provisions ensuring the conduct of scientific research and ensuring the availability of knowledge on the effects of climate change in priority sectors of the economy and possible approaches to adapt to them;

5) provide and disclose the mechanisms of lowcarbon development and revise the approaches to regulate the low-carbon development of the country, covering also the modernization and energy efficiency of the housing and communal sector and the development of "green" construction;

6) provide incentive measures for the transition of transport to alternative types of food (gas, electricity), including by reducing the import rate of component parts and electric vehicles and buses to $0 \%$, take into account the rules on preferential financing of electric vehicles (leasing).

The general part will consist of provisions of a general nature (the scope of regulation, purpose, objectives, subjects and objects, principles, sources, environmental management, rights and obligations of subjects; regulatory instruments; environmental information; environmental responsibility, etc.).

A special part will be devoted to environmental requirements with particularities in the types of natural resources (land, subsoil, water, forests, etc.), features of the legal protection of atmospheric air and the ozone layer; features in certain territories (specially protected natural territories; ecologically unfavorable territories, etc.); for certain types of activities; waste, etc.); climate change, greenhouse gas emissions.

Also, in the light of the widespread interpretation of the "polluter pays" principle, the polluters include not only people who actually harm the environment, but also those who only pose a risk to the environment in conditions when pollution has not (yet) occurred (e.g. companies involved in the production and distribution of potentially harmful products).In certain situations, the pollutant is also the final consumer of the product, in which case the pollutant "pays" indirectly, paying the costs of preventing and controlling pollution as part of the price of the product. To increase the environmental responsibility of consumers, many countries levy an environmental "product tax" (in addition to VAT and excise taxes): for example, in the Czech Republic, taxes on gas, fossil fuels, and electric energy have been levied since 2008; in Germany, such taxes have been levied since 1999; Japan levies taxes on oil, oil products, gas, coal, diesel and aviation fuel, and electricity. The main goal of such taxes is not replenishment of the budget, but a change in consumer behavior, the transition to more environmentally friendly products and the expected positive effect on the environment. At the same time, all collected "environmental taxes" are allocated exclusively for financing environmental protection.

Thus, the principle under consideration assumes a proportional distribution between the polluters of the economic burden of maintaining an acceptable environment, primarily the costs of "precautions and prevention" of pollution.

In Kazakhstan, like other countries in Eastern Europe, the Caucasus and Central Asia, the system of economic instruments for environmental regulation is significantly different from the system implemented in countries in Western Europe. While the latter mainly includes taxes on products, for example, on energy carriers, as well as target taxes on emissions / discharges of certain pollutants, Kazakhstan has a comprehensive and complex system of payments for emissions, covering a very large number of polluting substances and water, as well as solid waste generation and sulfur disposal. OECD countries distinguish between pollution charges and taxes. The term "payment" is used, as a rule, when a payment is made in exchange for a service. Non-refundable payments are usually referred to as taxes.

In Kazakhstan, all revenues from "environmental payments" (payments for emissions into the environment, fines, compensation for environmental damage, payments for nature use) are virtually not targeted. In practice, only a very small part of the funds raised goes as a result to solving environmental problems. At the same time, local representative bodies have the right to increase the rates of environmental payments by no more than two times, and in most regions of Kazakhstan the maximum possible rates are set.

Further, in the oil and gas industry there is an imbalance in the collection of fees, when for the emissions from gas flaring, the rates are much higher than the rates for emissions of similar pollutants at other stationary sources. International experts believe that such rates violate the "polluter pays" principle, since they place a heavier burden on payments for the oil and gas industry, while coal burning and the transport sector emit either a comparable or larger amount of pollutants. Among other things, the increase in rates for emissions from gas flaring in the Tax Code of the Republic of Kazakhstan led to high administrative fines for emissions of pollutants due to gas burning compared to emissions of the same pollutants from any other activity or facility. Such a result does not comply with the principles of administrative law, according to which the punishment must be fair and must correspond to the nature of the violation.

Currently, most of the oil and gas facilities in Kazakhstan burn a limited amount of gas, while the frequency of combustion and the volume of corresponding emissions are comparable with the frequency and volume of emissions at hydrocarbon production facilities operating in OECD countries, which reflects their use of the best available technologies. Gas combustion is controlled by state authorities and is almost completely reduced to 
technologically unavoidable situations. Moreover, the Code "On Subsoil and Subsoil Use" and regulatory legal acts adopted on its basis provide for a number of additional measures regulating the volumes and goals of gas flaring. In view of the above, the draft Code and the accompanying bill will eliminate the increased rates for flaring gas.

The above problems of law enforcement in the field of nature management and environmental protection, contradictions and gaps in environmental legislation require the creation of such a system of legal regulation that would help the state achieve its goal of ensuring a favorable environment for human life and health.

\section{List of sources:}

1. Zhakhanova L.Z. The human right to a favorable environment // Scientific community of students of the XXI century. Humanities: Sat. Art. by mat. XVI Int. Stud. scientific-practical conf. No. 1 (16). URL: $\quad$ http://sibac.info/archive/guman/1(16).pdf (accessed: 02/18/2019)

2. The Constitution of the Republic of Kazakhstan dated August 30, 1995. Almaty: Lawyer, 2013.

3. The Environmental Code of the Republic of Kazakhstan dated January 9, 2007. Almaty: Lawyer, 2013.

4. Elyubaev, Zh. S. Legislation of the Republic of Kazakhstan on environmental protection: problems of rulemaking and law enforcement / Zh. S. Elyubaev //
Traditions and innovations in law: international materials. scientific-practical Conf. 20th anniversary of legal Fak. and the 50th anniversary of Polotz. state University, Novopolotsk, October 6-7. 2017: at 3 t. / Polots. state University, Region. textbook.-scientificpractical. Jurid. center; editorial: I.V. Veger (ed. ed.) [et al.]. - Novopolotsk: Polotsk State University, 2017 .-V. 2. - P. 210.

5. Baideldinov D.L., Bekishova S.D. Environmental Law of the Republic of Kazakhstan. Almaty: Zhetizhargy, 2004 .-- 38 p.

6. Kulteleev S.T. Environmental Law of the Republic of Kazakhstan. - Almaty: Douir, 2003 .-- 328 p.

7. Nazarbayev N.A. A new stage in the democratization of Kazakhstan - the accelerated development of a free democratic society // Kazakhstanskaya Pravda. 2007 year - May 17th.

8. Baideldinov D.L. Environmental legislation of the Republic of Kazakhstan. - Almaty: Zhetizhargy, 1995 .-- $188 \mathrm{p}$.

9. Message from the President of the Republic of Kazakhstan to the people of Kazakhstan "Kazakhstan is on the verge of a new leap forward in its development". - Astana, 2006 [Electronic resource] // Official website of the President of the Republic of Kazakhstan. - Access mode: www.akorda.kz.

10. The concept of the draft new Environmental Code of the Republic of Kazakhstan, (August 2018).

\section{ВЗЫСКАНИЕ АЛИМЕНТОВ}

\section{Кинаят Ерасыл Досхожаұлы Магистрант КазГЮУ им. М.С.Нарикбаева}

\section{АННОТАЦИЯ}

В настоящее время основным законом, регулирующий вопрос взыскания алиментов является Закон “Об исполнительном производстве и статусе судебных исполнителей”. Однако исполнительные действия в области алиментов в данный момент являются проблематичными, исходя из анализа статистики. Предметом данной работы является взыскание алиментов и его проблематика.

Целью работы является исследование проблематики процесса взысканий алиментов согласно практике, закону.

В статье описываются основные проблемы взысканий алиментов и пути решения в РК, а также статистика исполнительных производств по взысканию алиментов и применения зарубежного опыта.

Исходя из исследования автора, были предложены определенные меры которые помогут дополнить законодательство и уменьшить на практике исполнительные производства в области алиментов.

Данная статья может быть интересна для студентов, магистрантов, докторантов, и всех лиц которых интересует данная тематика.

Ключевые слова: алименты, суд, должник, алиментные обязательства, судебный исполнитель, оплата

В современном мире взыскание алиментов играет важную роль в обеспечений лиц, которым необходим данный процесс.

«Дети - наиболее уязвимая и самая незащищенная часть нашего общества, и они не должны быть бесправными. Как Лидер нации, я буду требовать защиты прав каждого ребенка...» (из Послания Главы государства Стратегия «Казахстан-2050»)

Данный процесс общеизвестен во многих странах мира. Главным отличием взысканий алиментов в нашей стране от зарубежных стран, это недостаточность данного процесса и недостаточность ответственности и правосознания граждан.

Закон регулирующий взыскание алиментов это Закон “Об исполнительном производстве и статусе судебных исполнителей”.

Алименты - это средства необходимые для содержания ребенка, пожилого родителя которое выплачивает одно сторона (один из родителей, взрослый ребенок). 